\title{
Seasonal dynamics of plant species at fine scale in wooded pastures
}

\author{
F. Kohler ${ }^{1,2}$, F. Gillet ${ }^{1,2}$, M.-A. Progin ${ }^{2}$, J.-M. Gobat ${ }^{2}$ and A. Buttler ${ }^{1,3}$
}

\author{
${ }^{1}$ Swiss Federal Research Institute WSL, Antenne romande, CH-1015, Lausanne, Switzerland \\ 2 Department of Plant Ecology, Institute of Botany, University of Neuchâtel, Rue Emile-Argand 11, CH-2007 \\ Neuchâtel, Switzerland. Corresponding author.E-mail: florian.kohler@unine.ch \\ ${ }^{3}$ Department of Chronoecology, UMR CNRS 6565, UFR Sciences et Techniques, University of Franche-Comté, \\ F-25030 Besançon, France
}

Keywords: Carousel model, Cattle activity, Scale, Spatial monitoring, Species mobility, Turnover, Vegetation dynamics.

\begin{abstract}
A cell-grid method was used to survey seasonal changes in four herbaceous communities of a wooded pasture. Permanent plots consisted in $1-\mathrm{m}^{2}$ grids subdivided into 100 cells of $1 \mathrm{dm}^{2}$. In each cell of each plot and every month from May to September, we estimated dominance, and grazing occurrence of all species. Plant communities included an eutrophic grazed meadow, a temporary refused meadow, an underwood herb community and an oligotrophic lawn.
\end{abstract}

\begin{abstract}
Our results showed that seasonal changes in species composition were very strong and scale-dependent. Changes at plot scale were mainly driven by a seasonal shift. Changes at cell scale suggested high small-scale dynamics of species. Despite high changes at cell scale, the structure of the community did not change and local species richness did not show any trend. We found no correlation between the turnover at cell scale and cattle activity.

We conclude that dynamics and internal species turnover of the community at fine scale and short time seem more driven by internal characteristics of the community than by disturbances induced by cattle. Furthermore, at seasonal scale, plant communities may be
\end{abstract} stable in their structure despite fluctuations in their texture.

Nomenclature: Tutin et al. (1964-1980) for plants.

\section{Introduction}

Grassland communities are characterized by high small-scale turnover and spatial dynamics of plant species (Herben et al. 1993a, Van der Maarel and Sykes 1993, Otsus and Zobel 2002). This dynamics varies in space and in time within the community according to five different species strategies (Van der Maarel 1996): occasional, local, pulsating, circulating and constant. Palmer and Rusch (2001) have found in recent publications five factors associated with this high species turnover: weather fluctuations that promote establishment by seed, high rates of gap formation, a high proportion of species with short life spans, young age of clonal population and high number of potential colonizers. The role of small-scale dynamics in local species coexistence is still not clear. Otsus and Zobel (2002) made two assumptions: (1) for competitively inferior species, a high mobility could reduce the negative competition of dominant species by escaping in the available gaps; (2) for dominant species, the ability to occupy space efficiently may mean a superior competitive trait.
Van der Maarel and Sykes (1993) proposed the Carousel Model to describe this small-scale dynamics of vegetation. This model suggests that over time any microsite can become a niche for any species participating in the community. Wilson et al. (1995) proposed a variant of this model: the Niche-limited Carousel Model. In this model, there are only a limited number of niches within a microsite. This model predicts a relatively constant richness at fine-scale.

To explore the internal dynamics of an established plant community, the cell-grid method has been used since the middle of the last century (Watt 1962). This method consists in a repeated sampling of vegetation in several small cells. Most studies explored small dynamics with a temporal resolution of one year (e.g., Sykes et al. 1994, Van der Maarel and Sykes 1997, Klimes 1999, Zobel et al. 2000). Only few cases have a recording interval less than one year (Thórhallsdóttir 1990, Lafrage 2001). 
Our study was undertaken in a wooded pasture representing a typical landscape of the Swiss Jura mountains. This ecosystem is characterized by a mosaic of trees, shrubs and grassland grazed by cattle from May to September (Gallandat and Gillet 1999). Cattle activities, such as dung deposition, herbage removal (grazing s. s.) and trampling induce disturbance at short term and at fine scale. These three activities have different impacts on vegetation at a fine scale (bite and feeding station sensu Bailey et al. 1996). Dung pats and urine have two main effects on vegetation dynamics: (1) fertilization involving a stimulation of plant growth, and (2) reduction of the herbage attractiveness for cattle during the first months or years after deposition. Trampling affects the vegetation through detaching plant material with the hoof action and by influencing the water regime in firming the soil (Abdelmagid et al. 1987). Furthermore, trampling creates gaps and thus permits the establishment of new species (Grubb 1977). The effect of herbage removal is principally the loss of biomass and a change in light competition between species (Grime 2001).

The aim of the present work was to investigate at month scale and at two spatial scales $\left(1 \mathrm{dm}^{2}\right.$ and $\left.1 \mathrm{~m}^{2}\right)$ the dynamics of species in the herbaceous layer of four different typical plant communities in wooded pastures. At first, we described community dynamics at two spatial resolutions. Then, we were interested in the behaviour of each species and in its related dominance. After that, we investigated the relationship between the dynamics of species and cattle activity, in particular herbage removal and trampling. Note that the dynamics of plant species we consider here, which is sometimes called species mobility, must not be confounded with the mobility of plant individuals. The latter is quite impossible to investigate in mountain pastures, essentially composed by clones of perennial species for which the concept of individual is irrelevant.

We were guided by the following working hypotheses: (1) dynamics is higher at cell scale $\left(1 \mathrm{dm}^{2}\right)$ than at plot scale $\left(1 \mathrm{~m}^{2}\right)$; (2) changes at plot scale are driven by a phenological shift and thus are essentially directional at seasonal scale; (3) dynamics depends on species; (4) herbage removal by grazing depends on qualitative cattle selectivity and thus does not depend on species dominance; (5) selectively grazed species show higher dynamics at cell scale but remain constant at plot scale; (6) trampling increases species dynamics at cell scale.

At the end, we tried to use our results to learn which model (carousel model or niche-limited carousel model) could be relevant to explain the dynamics of plant species at seasonal scale in pastures.

\section{Material and methods}

Study site

This study was conducted in the Jura Mountains of north-western Switzerland. The study site is located in La Métairie d'Évilard (Orvin BE, $47^{\circ} 09^{\prime} \mathrm{N}, 7^{\circ} 10^{\prime} \mathrm{W}$ ) at an elevation of about $1200 \mathrm{~m}$ a.s.1. The climate is predominantly temperate oceanic, with mean annual rainfall of about $1600 \mathrm{~mm}$ (with more than $400 \mathrm{~mm}$ snow precipitation) and mean annual temperature of $7^{\circ} \mathrm{C}$. The ground is covered with snow from November to April. The area contains a great diversity of habitats, from open grasslands to forest patches, with flat or sloping ground and a heterogeneous soil mosaic (Leptosols, Cambisols, Luvisols; taxonomy after Deckers et al. 1998). This landscape is the result of decades of cattle activity. Climax vegetation is a beech forest. The management is extensive with a rotational grazing system. During the observation period in summer 2001, 120 heifers (49.2 Adult Bovine Units, $29520 \mathrm{~kg}$ live-weight) stayed three times (rotations) during 15 days in the period from May to September in the paddock where plots were placed (see below). Surface of the paddock was about 25 ha. The herd was a mix of Holstein and Swiss brown breeds.

\section{Sampling design}

We chose four typical community types building the mosaic of the herb layer in wooded pastures, constituted almost completely by perennial species. We placed preferentially one permanent plot in each of them.

The first chosen community was the most widespread in open areas, on soils of about $20 \mathrm{~cm}$ depth and with a $\mathrm{pH}$ close to 5 . This short-grass community was an 'eutrophic grazed meadow' dominated by Festuca nigrescens, Agrostis capillaris, Alchemilla monticola and Veronica chamaedrys. The second community occurred on the same soils, in mosaic in open areas with the first one, but with a higher canopy. This tall-grass community appeared generally where dung pats or urine have been left over by cattle, inducing an excess of nutrients that temporarily inhibits grazing behaviour. It is dominated by Festuca nigrescens, Sanguisorba minor, Taraxacum officinale and Cynosurus cristatus, and will be called 'temporary refused meadow' in this paper. The third community occurred also on the same soils, along the shaded edges of the thickets. This 'underwood herb community' was dominated by Carex montana, Fagus sylvatica (seedlings), Festuca nigrescens and Narcissus pseudonarcissus. The last chosen community was an 'oligotrophic lawn' (calcicolous dry grassland) dominated by Helianthemum nummularium subsp. obscurum, Hippocrepis co- 
mosa, Carex sempervirens and Koeleria pyramidata. It appeared in open areas on soils of about $5 \mathrm{~cm}$ depth and with a $\mathrm{pH}$ of about 6.5 . See Appendix 1, for a complete list of species and mean cover.

\section{Vegetation sampling}

We chose a spatial resolution of one square decimetre and an extent of one square meter using a square grid with one hundred cells. It was not possible to lay the grid down onto the soil because of the density of the vegetation. Thus, the grid was kept fifteen centimetres above the ground with four perforated plastic tubes. In order to place the grid every time in the same position, we fixed in the soil two other perforated plastic tubes at opposite corners. A wooden rod was then placed through the two superposed tubes to adjust the grid. The four plots were observed five times during the vegetation season, between May and September. In the whole study, 2000 cell-records were made. We recorded in each cell the exhaustive list of species and we estimated the absolute cover of each species with Braun-Blanquet's dominance code. Plants were often only at vegetative state and sometimes drastically grazed, inducing identification problems (Klimes et al. 2001) and indeed, this required training in species recognition. To reduce bias with this respect all records were made by the same observer. At each time, the plot records were constructed by aggregating the 100 cell records. Species absolute cover at plot scale was the mean of the species absolute cover in the 100 cells (deduced from dominance Braun-Blanquet's codes). Species frequency at each time was measured by dividing the sum of all occupied cells by 100 .

To get information on cattle activities, we recorded traces on grazing and trampling. We noted for every species for each cell if it has been grazed or not. Even if rough, this binary index appeared as a good compromise between precision and efficiency. Trampling effect was more difficult to assess. The size of a hoof corresponds to about one square decimetre and trampling disturbance is not selective. Therefore, we planted at the beginning of every rotation a $20 \mathrm{~cm}$ long vertical wooden stick into the ground in the middle of each cell and we checked later for broken or bent sticks. We may assume that this measure can be used as a rough binary index of trampling occurrence within the cell even if it could be due to another cattle activity, such as grazing. At plot scale, trampling intensity at each time was calculated by summing all occurrences.

Each record of one square meter required five to eight hours of labour or more, depending of the species richness and on the state of development of the vegetation. Our sampling design did not permit to study dunging and gap creation because these two disturbances were too rare and localised.

\section{Statistical analysis}

At first, we studied the dynamics from a community point of view. To know if the seasonal dynamics depended on spatial scale, we calculated the richness and the cumulative richness of species (Van der Maarel et al. $1995)$ per cell $\left(1 \mathrm{dm}^{2}\right)$ and per plot $\left(1 \mathrm{~m}^{2}\right)$. Furthermore, to assess the spatial arrangement of the community through time, we calculated for all vegetation records within each plot and at each session the Mantel correlogram with Pearson's correlation coefficient using the $\mathrm{R}$ package (Casgrain and Legendre 2001).

Secondly, we studied the dynamics at a population point of view. To detect different specific behaviours, we defined three exclusive strategies for species according to their dynamics:

- Casual: species appearing only once, except in May and September,

- Pulsating: species disappearing and appearing newly during the season,

- Persistent: species remaining at least through two successive months and which were not pulsating.

Contrary to Van der Maarel (1996) who took into account spatial and temporal aspects, this classification uses only time series of one plot or cell. This classification excludes vernal and late species, which appeared only in May or in September, because we do not know what happened before or after that period. Furthermore, because we did not have any control on underground patterns, it is possible that some extinction events represented only disappearance of aboveground shoots, for example, after grazing. It is important to remember that our study does not consider individuals but instead species. We calculated at plot and cell scale the percentage of species showing at least one of the three strategies. At cell scale, this was done by checking the species behaviour over the five records carried out in the same cell. At plot scale the five $1 \mathrm{~m}^{2}$ records were used instead. Thus, at cell scale one species may behave according to more than one strategy. So, we calculated for each species the relative importance of each strategy using the hundred cells per plot.

Thirdly, we assessed the role of cattle activity in the community dynamics at both scales. We calculated for each cell the grazing intensity as the sum of the relative cover (deduced from Braun-Blanquet codes) of all individual species that were grazed after each rotation. Fur- 
thermore, for each plot at each session, we calculated the percentage of broken sticks.

Spearman rank correlations were used to investigate the relationship between the mean annual turnover (mean of turnover in a cell during the study) and the mean annual grazing intensity (mean of grazing intensity in a cell during the study) or the total trampling occurrences (number of sticks broken in a cell during the study). The turnover between consecutive sessions was calculated by using Jaccard's dissimilarity index (1 - Jaccard's binary similarity, Güsewell et al. 1998). Because data in contiguous grid samples are autocorrelated (Jonsson and Moen 1998), we corrected the degree of freedom and the $P$ value, accounting for spatial autocorrelation, by the method of Dutilleul (1993) when testing the Spearman rank correlation. This correction was computed with the Mod_t_test program (Legendre 2001).

From a population point of view, Spearman rank correlation was also used to investigate in each plot for each species the relationship between the relative importance of the three strategies (see above), or the mean annual cover of the species (annual mean species cover of all records) and the mean grazed species cover (annual mean of the proportion of species cover with traces of grazing).
Except the correction of Dutilleul (1993) and the correlograms of Mantel, all calculations were performed with R 1.8.1 (R Development Core Team 2003).

\section{Results}

\section{Community point of view}

The evolution of species richness and cumulative species richness in the different vegetation types at cell scale and at plot scale is shown in Fig. 1. In each plot, the mean number of species per cell did not show any obvious trend whereas the cumulative richness increased. The maximum cumulative number of species per cell was increasing up to about half of the total cumulative number of species per plot. The lawn pattern appeared as the most constant with a small difference between the number and cumulative number of species. At this scale, the four vegetation types showed globally the same behaviour. By contrast, at plot scale the richness varied with a maximum in June for the temporary refused meadow, the underwood and the lawn, and in September for the grazed meadow. In the lawn, the underwood and the temporary refused meadow, the cumulative richness increased dramatically in June and more gently after. Correlograms of Mantel (Fig. 2) showed at each period and for all vegetation types significant positive autocorrelation for short distances. This spatial autocorrelation was highest in the
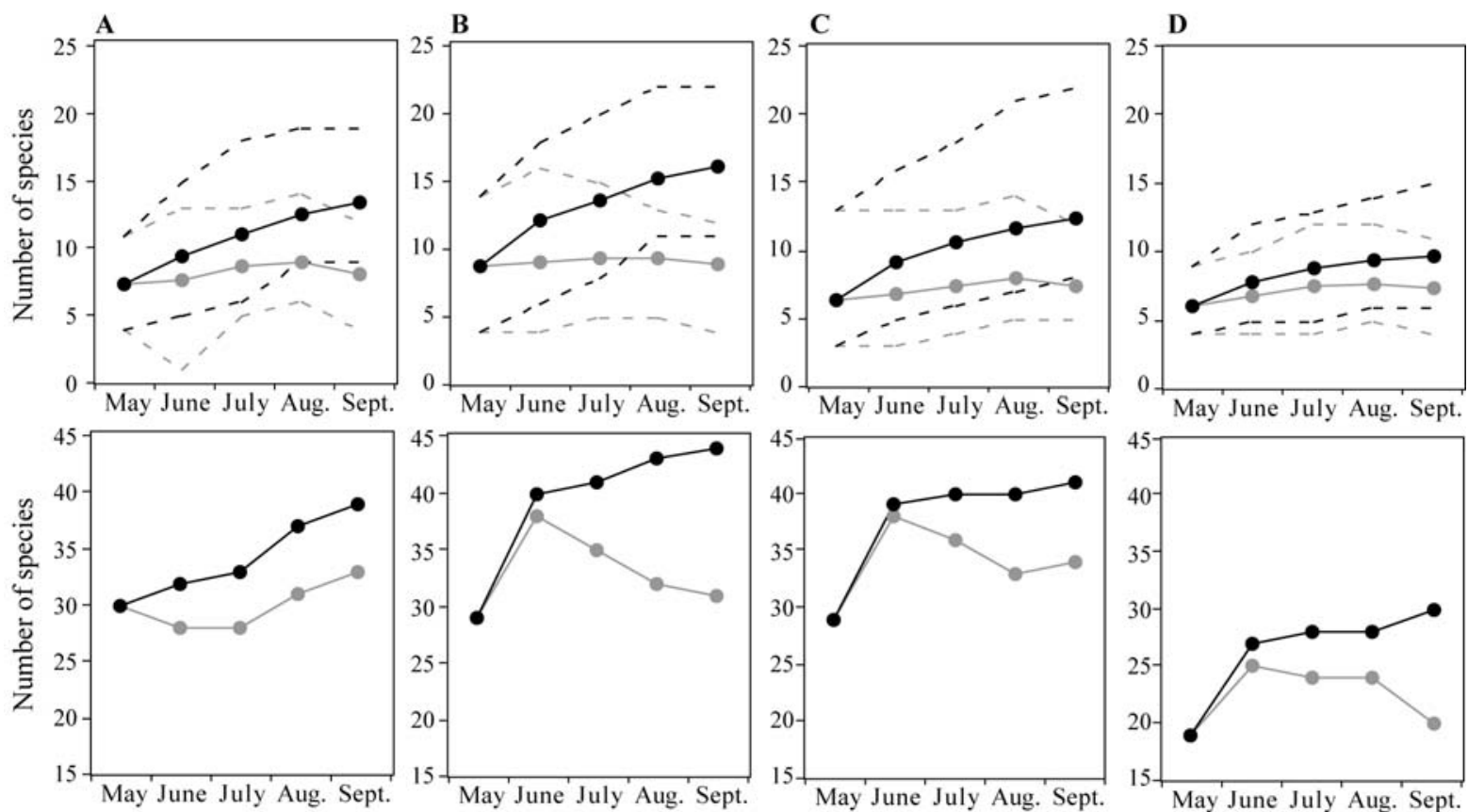

Figure 1. Species richness (grey lines) and cumulative species richness (black lines) in four vegetation types (A: grazed meadow, B: temporary refused meadow, C: underwood, D: lawn) from May to September. At 1- $\mathrm{dm}^{2}$ scale (above), mean (solid lines), and maximum and minimum (dashed lines) are represented. At $1-\mathrm{m}^{2}$ scale (below), absolute values are given. 


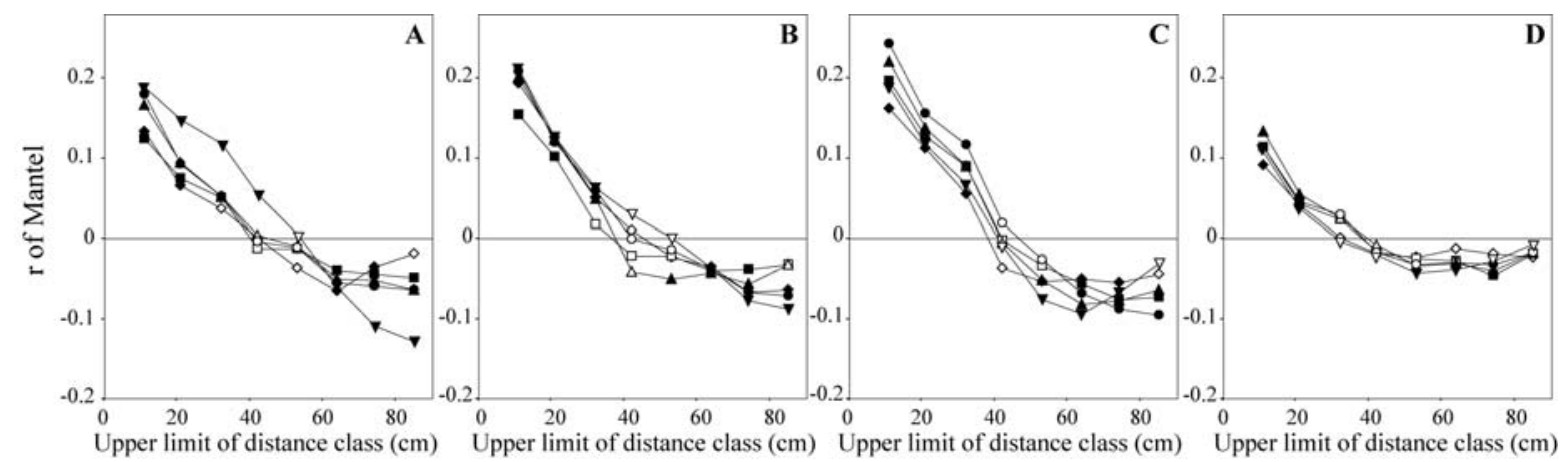

Figure 2. Mantel correlograms with Pearson's correlation coefficient between vegetation records in 1-dm ${ }^{2}$ cells of each plot at each session. Diamonds: May; squares: June; triangles upper: July; dots: August; triangles lower: September. Full: significant $P$ value (0.05) with correction of Bonferroni. A: grazed meadow; B: temporary refused meadow; C: underwood; D: lawn.

underwood and lowest in the lawn. There were significant negative values for longer distances, except in the lawn where only few negative values were significant. The general pattern did not vary over the season in any of the communities except for the grazed meadow in September. At this time, the correlogram was more contrasted with higher positive values at small distances and higher negative values for longer distances.
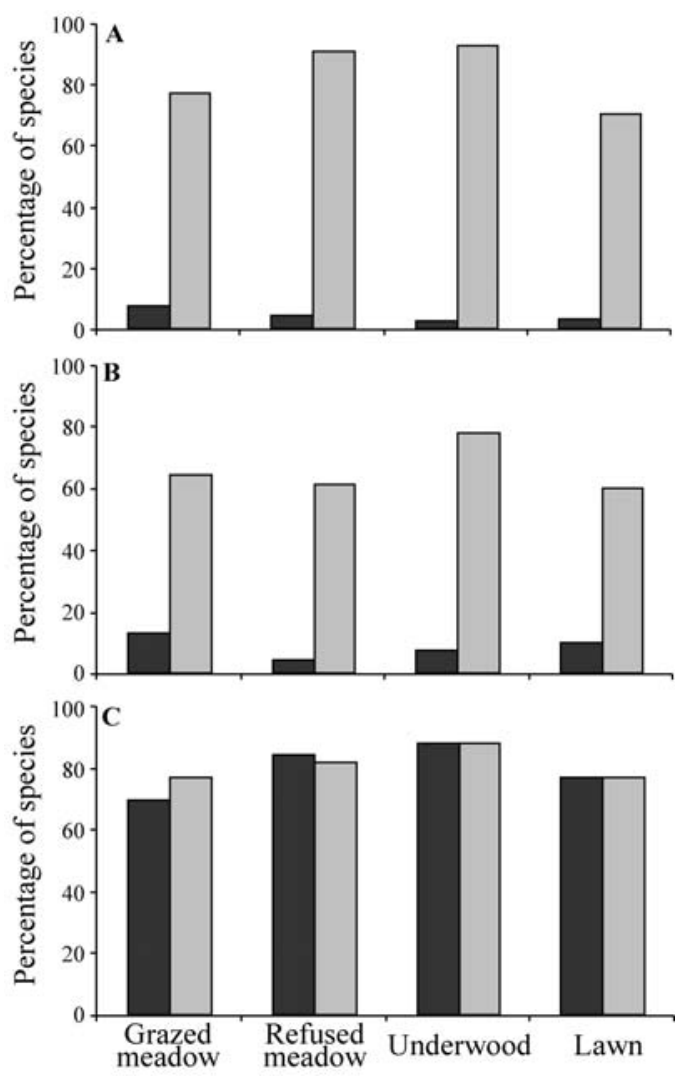

Figure 3. Percentage of species appearing at least once with the strategy casual (A), pulsating (B) and persistent (C) at plot (black) and cell (grey) scale.

\section{Population point of view}

At plot scale, most of the species were persistent and only few were casual or pulsating (Fig. 3). This means that almost all species appeared at one moment, persisted during at least two months and disappeared. On the other hand, at cell scale almost all species could behave as persistent, pulsating or casual. Fig. $4 \mathrm{a}$ and $\mathrm{b}$ show for each species ordered by annual mean frequency the relative percentage of each strategy. The persistent strategy dominated generally, but in each vegetation type some species presented an important proportion of the two other strategies. By definition, species with high frequency are persistent because even if individuals or clones moved there is a high probability that they occupied a cell already occupied at the last session. This explains why the persistent strategy dominated for the most frequent species. Thus, it is more interesting to consider species with medium or low frequency. For species with medium frequency, the persistent strategy dominated. There were some exceptions. For example, in the grazed meadow, the temporary refused meadow and the underwood, Rumex acetosa showed a large proportion of pulsating and casual behaviour. Crepis mollis in the grazed meadow and in the underwood, Anthoxantum odoratum in the temporary refused meadow, Veronica officinalis in the underwood or Potentilla crantzii in the lawn presented also a high proportion of pulsating and casual strategies. Species with a low frequency showed generally a high proportion of casual behaviour. There were in this case also some exceptions such as Potentilla erecta in the grazed meadow or in the temporary refused meadow.

\section{Cattle activity}

The pattern of herbage removal in June after the first rotation and in September at the end of the season was 

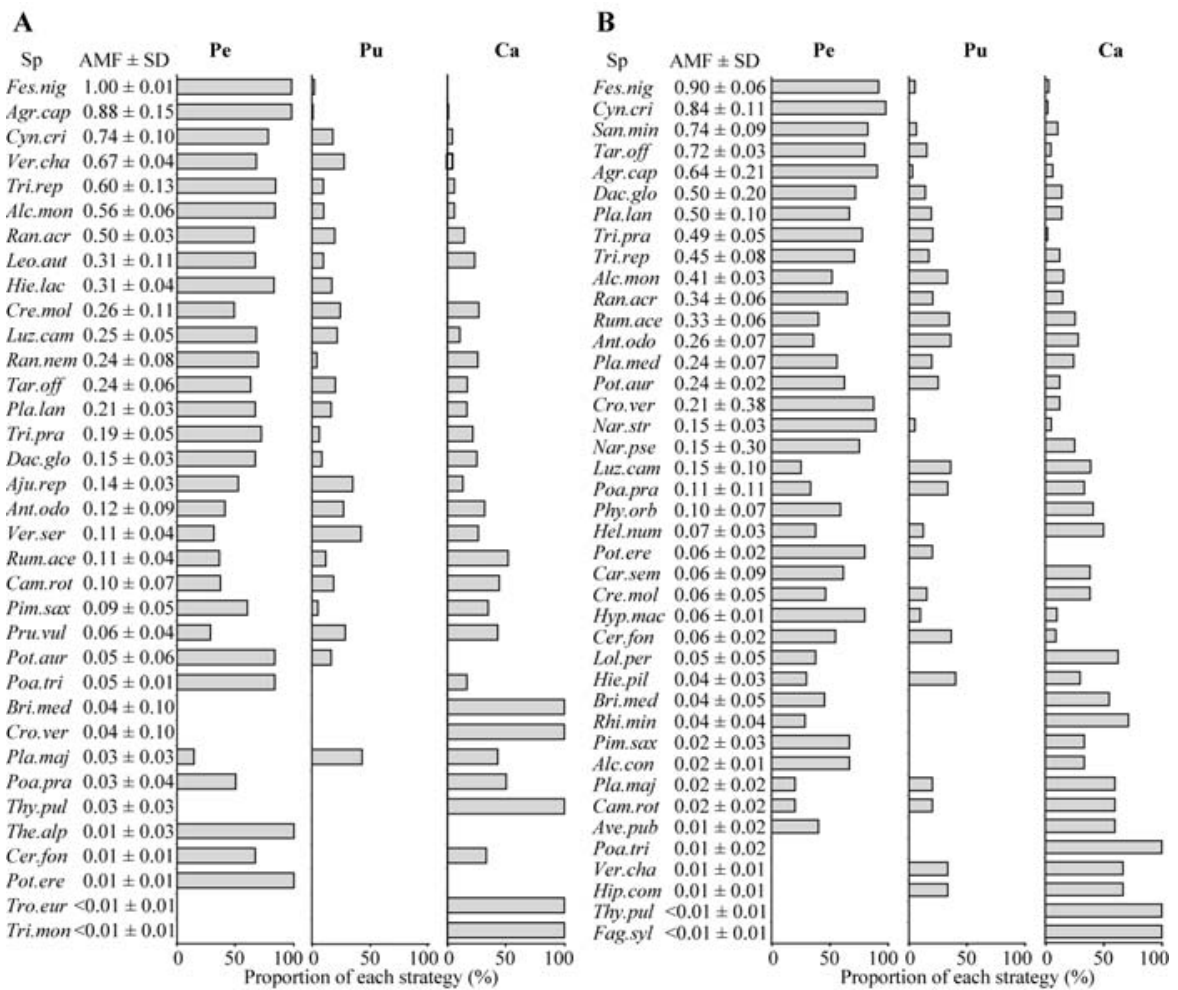

Figure 4a. Proportion of observed strategies at cell scale for all species. Vernal and late species were excluded (see explanation in the text). $\mathrm{AMF} \pm \mathrm{SD}$ : annual mean frequency \pm standard deviation; Pe: persistent; Pu: pulsating; Ca: casual; A: grazed meadow; B: temporary refused meadow. For species abbreviations see Appendix 1.

C

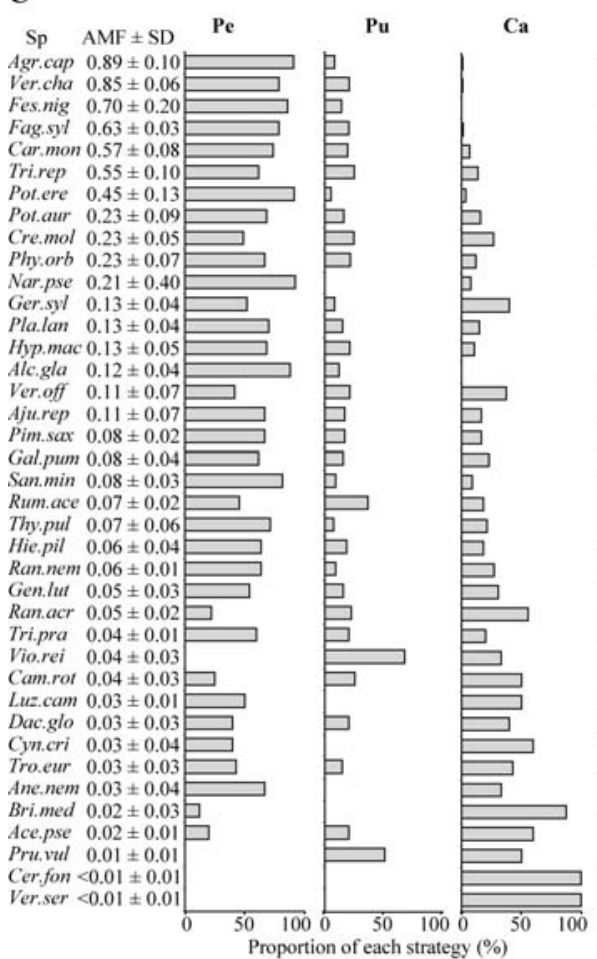

D

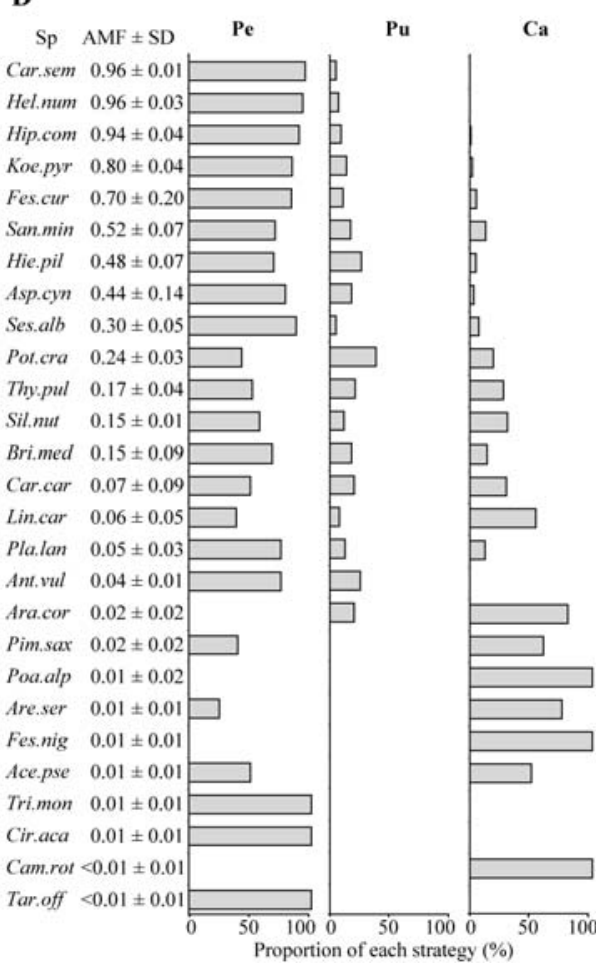

Figure 4b. Proportion of observed strategies at cell scale for all species. Vernal and late species were excluded (see explanation in the text). $\mathrm{AMF} \pm \mathrm{SD}$ : annual mean frequency \pm standard deviation; Pe: persistent; Pu: pulsating; Ca: casual; C: underwood; D: lawn. For species abbreviations see Appendix 1. 

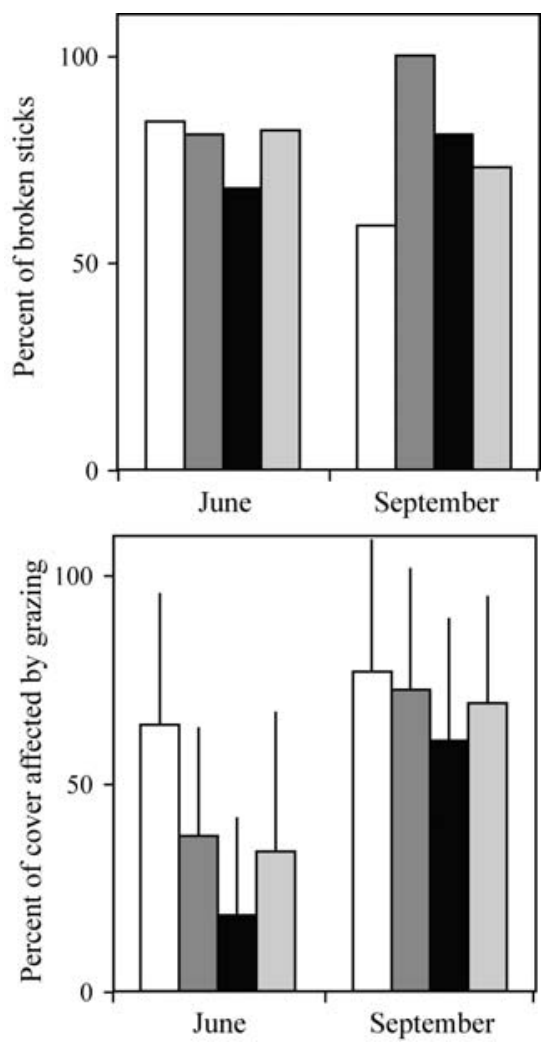

Figure 5. Proportion of broken sticks for the entire plot (100 cells) and mean with standard deviation of amount of vegetation cover affected by grazing per cell (grazing intensity) in each vegetation type after the first rotation (June) and after the last one (September). White: grazed meadow; dark grey: temporary refused meadow; black: underwood; light grey: lawn.

completely different (Fig. 5). In June, the grazed meadow was the most grazed and in September the four communities were almost equally intensively grazed. The variation was very high, indicating that at very fine scale the pattern of herbage removal was very heterogeneous. In the grazed meadow, for example, some cells were never grazed despite a high grazing rate in neighbouring cells. The situation was very different for trampling occurrence. In June, an equal high number of broken sticks was recorded in all communities, indicating that every community was visited. In September, there were more broken sticks in the temporary refused meadow and less in the grazed meadow.

From a community point of view, there was no correlation between the mean turnover and the grazing intensity or the trampling occurrence (results not shown). From a population point of view, there were some significant positive correlations between persistent strategy and the mean grazed species cover (Table 1). Pulsating strategy was positively correlated as well, whereas casual strategy
Table 1. Spearman rank correlation between for each species the annual mean grazed species cover $(\mathrm{G})$ and the proportion of strategies (Pe: persistent, $\mathrm{Pu}$ : pulsating or $\mathrm{Ca}$ : casual) in the 100 cells or the mean annual species cover (Co) (see details in the text). $\bullet<P 0.1, *<P 0.05,{ }^{* *} P<$ $0.01, * * * P<0.001$.

\begin{tabular}{lcccc}
\hline & Pe vs, G & Pu vs. G & Ca vs. G & Co vs G \\
\hline Grazed meadow & $\mathbf{0 . 3 2 *}$ & 0.27 & $\mathbf{- 0 . 3 0 ^ { * }}$ & $\mathbf{0 . 5 2}^{* * *}$ \\
Temporary refused meadow & $\mathbf{0 . 3 5 ^ { * }}$ & 0.09 & $-\mathbf{0 . 3 8 ^ { * }}$ & $\mathbf{0 . 4 6}^{* *}$ \\
Underwood & 0.24 & $0.28^{*}$ & $\mathbf{- 0 . 3 3 ^ { * }}$ & $\mathbf{0 . 3 4}^{*}$ \\
Lawn & $\mathbf{0 . 5 1 ^ { * * }}$ & $\mathbf{0 . 4 4 ^ { * }}$ & $\mathbf{- 0 . 5 4 ^ { \star * }}$ & $\mathbf{0 . 8 6}^{* * *}$ \\
\hline
\end{tabular}

was negatively correlated with grazing intensity. Additionally, all correlations between cover and grazing intensity were significant, indicating that a species with a high cover had more chance to be grazed than a low-covering species. Thus, there was no clear selection of species at this scale.

\section{Discussion}

\section{Change in species assemblage and scale effect}

Our results showed that seasonal changes in species composition and distribution were very strong and scaledependent. At plot scale, changes can be explained mainly by a phenological shift, due to life-history traits of species. Indeed, most of the species appeared at one time, persisted in the community at least for two months (persistent type) and disappeared after finishing their life cycle or were waiting for the next favourable season. By contrast, changes at cell scale were only partially due to the phenological shift. Dynamics of species plays an important role at this scale. Almost every species can either appear only once (casual) or disappear and then reappear during the season (pulsating). Herben et al. (1993b) observed the same phenomenon at annual scale with high dynamics at $3.3 \mathrm{~cm} \mathrm{x} 3.3 \mathrm{~cm}$ and low dynamics at $50 \mathrm{~cm}$ x $50 \mathrm{~cm}$. They conclude that at small scale forces act on species composition so as to make dynamics non-directional. Furthermore, Pärtel and Zobel (1995) concluded that both relatively stable and successional communities show a similar high small-scale turnover. Also, the spatial autocorrelation pattern was constant over time, indicating that the spatial structure of the community did not change during the season, despite changes in the floristic composition. Therefore, at fine and seasonal scale and despite changes in the vegetation texture, the structure seems to be very persistent in the four communities with different ecological characteristics. The community with the lowest dynamics was the lawn. This vegetation type which grows with low soil nutrient availability and in dry conditions has a low growth rate and consequently probably also less ability to move its species. We can also suppose that this vegetation, with the lowest height and cover, in- 
duced less competition between species for space and that there was therefore less strength for a high spatial dynamics. Nevertheless, Chiarucci et al. (2002) suggested recently that physical space is probably never limiting by itself in terrestrial higher-plant communities.

\section{Species strategies}

Different species showed a contrasting proportion of the three strategies. Otsus and Zobel (2002) observed also high differences among species for vegetative turnover. We can explain the high proportion of casual and pulsating behaviours for medium-frequency species by three different strategies to maintain the population: (1) adult plants are very mobile, (2) adult plants are not mobile at all but there is a flush of seedling establishment which die soon before reaching any significant cover and (3) adult plants have a high regenerative potential after having been completely grazed (pulsating behaviour). On the basis of the present data, we cannot distinguish between these three strategies but there is some indication that all of them are involved. The high proportion of species with clonal reproduction in grasslands (Tamm et al. 2002, Klimes et al. 1997) points to a high possibility to adult plants to move. The importance of the second strategy is less clear. Marriott et al. (2002) concluded that in the closed canopy of the grazed meadow there is little opportunity for seedling development whereas Jakobsson and Eriksson (2000) who sown 50 species in undisturbed grasslands found that $90 \%$ of the species established recruits. About the third strategy, Lardner et al. (2002) showed a high availability of some grass species to regrow rapidly after sheep grazing. Furthermore, Klimes and Klimesova (2002) suggested that higher regrowth ability of less competitive grasses could explain species coexistence in species-rich meadows.

For species with weaker competitive ability, we can interpret the casual behaviour as a means to escape competition (Huckle et al. 2000). In plots of $10 \mathrm{~m}^{2}$ Collins and Glenn (1991) have shown that at small spatial scales there is a high degree of stochastic variation over time among satellite species (locally less abundant) within a stable matrix of core species (locally more abundant).

\section{Dynamics of species and cattle activity}

Concerning the effect of cattle activities on this dynamics, results were less clear. There was no evidence of direct influence of these activities on the turnover of the community, perhaps due partially to the lack of precision of our indices of grazing and trampling. These results could have been explained by supposing a homogeneous pattern of grazing at fine scale but this was clearly not the case (Fig. 5). Furthermore, at plot scale for the temporary refused meadow or for the lawn there was a clear shift of the importance of grazing during the season and indeed this illustrates the well-known process of broadening of the exploration by cattle, which makes that more vegetation types are eaten when the season goes on. This clear shift in cattle activity did not seem to induce particular dynamics in the plant community. The number or the cumulative number of species at cell scale for the lawn and the temporary refused meadow showed the same trend as the grazed meadow, which was always highly grazed during the season. The absence of links between cattle activities and seasonal turnover at small scale could be explained by the fact that internal dynamics of communities caused by non-linearities in system structure (Herben et al. 1993a) dominate at fine scale, cattle activities acting at larger space and time scales.

There was no evidence in our results for selectivity of species by cattle grazing. The more a species has a high cover, the more it is eaten. Grant et al. (1985) explained this incapacity of cattle to select species at fine scale by its mouthparts form. Positive correlation between persistent strategy and grazing intensity seemed not causal and could be explained by an indirect correlation induced by the amount of cover, which was positively correlated with the removed biomass. On the other hand, this positive correlation could explain the highest mobility of less abundant species. By grazing the more covering species, cattle created free space where other species could immigrate. Positive correlation with the pulsating strategy could be explained by the fact that a high herbage removal may induce a disappearance of aboveground parts, which can reappear later. Like with the persistent strategy, negative correlations with the casual behaviour seemed not causal and could be explained by an indirect correlation induced by the species cover.

\section{Carousel model}

Many species showed a constant frequency during the season (species with a low SD in Fig. 4a and b) while dynamically active (fairly high proportion of pulsating or casual behaviour), suggesting a carousel at this time scale. This result implies that the 'Carousel times' calculated by Palmer and Rusch (2001) with time resolution of one year could be faster in reality. Ranunculus acris occupied in the grazed meadow at a given time $55 \%$ of the cells but it was observed at least once in $84 \%$ of the cells during the season, which makes a difference of $151 \%$. This example shows the importance of having an adequacy between time and space scales. Another interesting result is that the mean number of species per cell did not show any trend 
over time in each cell despite high fluctuations at plot scale (Fig. 1) and high proportion of casual and pulsating strategies (Figs 3 et 4). These results seem to be on line with the 'Niche-limited Carousel Model' of Wilson et al. (1995), even if they cannot fully support it. This model supposes that species are mobile in the community but can emigrate in a microsite only if a species disappears.

In conclusion, dynamics and internal species turnover of the community at fine scale and short time seem to be more driven by internal characteristics of the community rather than by disturbances induced by cattle. The latter plays a role at larger scale (more than $1 \mathrm{~m}^{2}$ ) by maintaining the composition and the structure of the different communities (Kohler et al. 2004). Furthermore, at seasonal scale, plant communities may be stable in their structure despite fluctuations in their texture.

Acknowledgements. We acknowledge support from the Swiss National Science Foundation (subside 31- 64116.00 and NCCR Plant Survival). We would also like to thank two anonymous reviewers for critically commenting on the manuscript. This paper was an oral contribution at the Symposium "State of the Art in Vegetation Monitoring Approaches", Birmensdorf 2003.

\section{References}

Abdelmagid, A.H., M.J. Trlica and R.H. Hart. 1987. Soil and vegetation responses to simulated trampling. J. Range. Manage. 40:303-306.

Bailey, D.W., J.E. Gross, E.A. Laca, L.R. Rittenhouse, M.B. Coughenour, D.M. Swift and P.L. Sims. 1996. Mechanisms that result in large herbivore grazing distribution patterns. J. Range. Manage. 49:386-400.

Casgrain, P. and P. Legendre 2001. The R Package for Multivariate and Spatial Analysis, Version 4.0 d4 - User's Manual. Département de sciences biologiques, Université de Montréal. http://www.fas.umontreal.ca/BIOL/legendre/

Chiarucci, A., M. Mistral, I. Bonini, B.J. Anderson and J.B. Wilson. 2002. Canopy occupancy: How much of the space in plant communities is filled? Folia Geobot. Phytotax. 37:333-338.

Collins, S.L. and S.M. Glenn. 1991. Importance of spatial and temporal dynamics in species regional abundance and distribution. Ecology 72:654-664.

Deckers, J.A., F.O. Nachtergaele and O.C. Spaargaren (eds). 1998. World Reference Base for Soil Resources: Introduction. Publishing Company Acco, Leuven, NL.

Dutilleul, P. 1993. Modifying the T-test for assessing the correlation between two spatial processes. Biometrics 49:305-314.

Gallandat, J.-D. and F. Gillet. 1999. Le pâturage boisé jurassien. Bull. Soc. Neuchâtel. Sci. Nat. 122:5-25.

Grant, S.A., D.E. Suckling, H.K. Smith, L. Torvell, T.D.A. Forbes and J. Hodgson. 1985. Comparative studies of diet selection by sheep and cattle - the hill grasslands. J. Ecol. 73:987-1004.

Grime, J.P. 2001. Plant Strategies, Vegetation Processes, and Ecosystem Properties. Wiley, Chichester, UK.

Grubb, P.J. 1977. The maintenance of species-richness in plant communities: The importance of the regeneration niche. Biol. Rev. 52:107-145.
Güsewell, S., A. Buttler and F. Klotzli. 1998. Short-term and longterm effects of mowing on the vegetation of two calcareous fens. J. Veg. Sci. 9:861-872.

Herben, T., F. Krahulec, V. Hadincová and M. Kovárová. 1993a. Small-scale spatial dynamics of plant-species in a grassland community over six years. J. Veg. Sci. 4:171-178.

Herben, T., F. Krahulec, V. Hadincová and H. Skálová. 1993b. Small-scale variability as a mechanism for large-scale stability in mountain grasslands. J. Veg. Sci. 4:163-170.

Huckle, J.M., J.A. Potter and R.H. Marrs. 2000. Influence of environmental factors on the growth and interactions between salt marsh plants: effects of salinity, sediment and waterlogging. $J$. Ecol. 88:492-505

Jakobsson, A. and O. Eriksson. 2000. A comparative study of seed number, seed size, seedling size and recruitment in grassland plants. Oikos 88:494-502.

Jonsson, B.G. and J. Moen. 1998. Patterns in species associations in plant communities: the importance of scale. J. Veg. Sci. 9:327332.

Klimes, L. 1999. Small-scale plant mobility in a species-rich grassland. J. Veg. Sci. 10:209-218.

Klimes, L., M. Dancák, M. Hájek, I. Jongepierová and T. Kucera. 2001. Scale-dependent biases in species counts in a grassland. $J$. Veg. Sci. 12:699-704.

Klimes, L. and J. Klimesova. 2002. The effects of mowing and fertilization on carbohydrate reserves and regrowth of grasses: do they promote plant coexistence in species-rich meadows? Evol. Ecol. 15:363-382.

Klimes, L., J. Klimesova, R. Hendriks and J. van Groenendael. 1997. Clonal plant architecture: a comparative analysis form and function. In: H. de Kroon and J. van Groenendael (eds.), The Ecology and Evolution of Clonal Plants. Backhuys Publishers, Leiden, NL, pp 1-29.

Kohler, F., F. Gillet, J.-M. Gobat and A. Buttler. 2004. Seasonal vegetation changes in mountain pastures due to simulated effects of grazing. J. Veg. Sci. 15:143-150.

Lafarge, M. 2001. Three approaches for analysing the dynamics of the horizontal layout of tillers in grass patches. Application to tall fescue swards surveyed over two growing seasons. Acta Oecol. 22:109-119.

Lardner, H.A., S.B.M. Wright and R.D.H. Cohen. 2002. Leaf development of eight grass species following grazing. Can. J. Plant Sci. 82:747-750.

Legendre P. 2001. Program Mod_t_test. Département de sciences biologiques, Université de Montréal. http://www.fas.umontreal.ca/BIOL/legendre/

Mariott, C.A., G.R. Bolton, G.T. Barthram, J.M. Fisher and K. Hood. 2002. Early changes in species composition of upland sown grassland under extensive grazing management. Appl. Veg. Sci. 5:87-98.

Otsus, M. and M. Zobel. 2002. Small-scale turnover in a calcareous grassland, its pattern and components. J. Veg. Sci. 13:199-206.

Palmer, M.W. and G.M. Rusch. 2001. How fast is the carousel? Direct indices of species mobility with examples from an Oklahoma grassland. J. Veg. Sci. 12:305-318.

Pärtel, M. and M. Zobel. 1995. Small-scale dynamics and species richness in successional alvar plant-communities. Ecography 18:83-90.

R Development Core Team. 2003. R: A Language and Environment for Statistical Computing. R Foundation for Statistical Computing, Vienna, Austria. http://www.R-project.org 
Sykes, M.T., E. Van der Maarel, R.K. Peet and J.H. Willems. 1994 High species mobility in species-rich plant-communities - an intercontinental comparison. Folia Geobot. Phytotax. 29:439-448.

Tamm, A., K. Kull and M. Sammul. 2002. Classifying clonal growth forms based on vegetative mobility and ramet longevity: whole community analysis. Evol. Ecol. 15:383-401.

Thórhallsdóttir, T.E. 1990. The dynamics of a grassland community: a simultaneous investigation of spatial and temporal heterogeneity at various scales. J. Ecol. 78:884-908.

Tutin, T.G., V.H. Heywood, N.A. Burges, D.H. Valentine, S.M. Walters and D.A. Webb. 1964-1980. Flora Europaea. Cambridge University Press. Vol. 1-5.

Van der Maarel, E. 1996. Pattern and process in the plant community: Fifty years after A.S. Watt. J. Veg. Sci. 7:19-28.

Van der Maarel, E., V. Noest and M.W. Palmer. 1995. Variation in species richness on small grassland quadrats: niche structure or small-scale plant mobility? J. Veg. Sci. 6:741-752.

Van der Maarel, E. and M.T. Sykes. 1993. Small-scale plant species turnover in a limestone grassland: the carousel model and some comments on the niche concept. J. Veg. Sci. 4:179-188.

Van der Maarel, E. and M.T. Sykes. 1997. Rates of small-scale species mobility in alvar limestone grassland. J. Veg. Sci. 8:199208.

Watt, A.S. 1962. The effect of excluding rabbits from grassland A (xerobrometum) in Breckland, 1936-60. J. Ecol. 50:181-198.

Wilson, J.B., M.T. Sykes and R.K. Peet. 1995. Time and space in the community structure of a species-rich limestone grassland. $J$. Veg. Sci. 6:729-740.

Zobel, M., M. Otsus, J. Liira, M. Moora and T. Möls. 2000. Is smallscale species richness limited by seed availability or microsite availability? Ecology 81:3274-3282.

Appendix 1: Mean absolute cover in percent (deduced from dominance Braun-Blanquet's codes) of species for the five consecutive plot records in the four communities (A: grazed meadow, B: temporary refused meadow, C: underwood, D: lawn).

\begin{tabular}{|c|c|c|c|c|c|}
\hline Species & Abrev. & $\mathbf{A}$ & B & $\mathrm{C}$ & D \\
\hline Acer pseudoplatanus & Acepse & - & - & 0.05 & 0.07 \\
\hline Agrostis capillaris & Agr cap & 16.87 & 4.52 & 8.03 & $\cdot$ \\
\hline Ajuga reptans & Aju rep & 1.66 & - & 1.65 & - \\
\hline Alchemilla conjuncta & Alc con & - & 0.17 & - & - \\
\hline Alchemilla glabra & Alc gla & 0.03 & - & 1.83 & - \\
\hline Alchemilla monticola & Alc mon & 10.50 & 5.25 & - & - \\
\hline Anemone nemorosa & Ane nem & - & - & 1.33 & - \\
\hline Anthoxanthum odoratum & Ant odo & 0.80 & 1.43 & - & - \\
\hline Anthyllis vulneraria subsp. vulneraria & Ant vul & - & - & - & 0.54 \\
\hline Arabis corymbiflora & Aracor & - & - & - & 0.14 \\
\hline Arenaria serpyllifolia & Are ser & - & - & - & 0.01 \\
\hline Asperula cynanchica & Asp cyn & - & - & - & 3.24 \\
\hline Avenula pubescens subsp. pubescens & Ave pub & - & 0.11 & - & - \\
\hline Briza media subsp. media & Brimed & 1.97 & 0.33 & 0.20 & 0.44 \\
\hline Campanula rotundifolia & Cam rot & 0.38 & 0.05 & 0.14 & 0.03 \\
\hline Carex caryophyllea & Car cay & - & 0.49 & - & 0.41 \\
\hline Carex montana & Car mon & - & - & 11.23 & - \\
\hline Carex sempervirens & Car sem & - & 0.28 & - & 13.43 \\
\hline Cerastium fontanum subsp. triviale & Cerfon & 0.05 & 0.25 & 0.03 & 0.03 \\
\hline Cirsium acaule subsp. acaule & Cir aca & - & - & - & 0.01 \\
\hline Crepis mollis & Cre mol & 2.04 & 0.56 & 2.21 & - \\
\hline Crocus vernus subsp. albiflorus & Crover & 0.47 & 5.56 & 0.83 & - \\
\hline Cynosurus cristatus & Cyncri & 6.47 & 10.54 & 0.29 & - \\
\hline Dactylis glomerata subsp. glomerata & Dac glo & 1.84 & 6.82 & 0.26 & - \\
\hline Fagus sylvatica & Fag syl & - & $<0.01$ & 10.34 & $\cdot$ \\
\hline Festuca curvula subsp. curvula & Fes cur & - & - & $\cdot$ & 3.88 \\
\hline Festuca nigrescens subsp. nigrescens & Fes nig & 36.63 & 24.19 & 10.06 & 0.02 \\
\hline Galium pumilum & Gal pum & - & - & 0.50 & - \\
\hline Gentiana lutea & Gen lut & - & $\cdot$ & 0.94 & - \\
\hline Geranium sylvaticum subsp. sylvaticum & Ger syl & $\cdot$ & $\cdot$ & 1.98 & - \\
\hline Helianthemum nummularium subsp. obscurum & Hel num & - & 0.54 & $\cdot$ & 18.32 \\
\hline Hieracium lactucella & Hie lac & 4.44 & - & - & - \\
\hline Hieracium pilosella subsp. pilosella & Hie pil & 0.03 & 0.46 & 0.95 & 4.39 \\
\hline Hippocrepis comosa & Hip com & - & 0.30 & - & 18.20 \\
\hline Hypericum maculatum subsp. maculatum & Hyp mac & - & 0.32 & 1.33 & - \\
\hline Koeleria pyramidata & Koe pyr & - & - & - & 8.30 \\
\hline
\end{tabular}




\begin{tabular}{|c|c|c|c|c|c|}
\hline Species & Abrev. & $\mathbf{A}$ & B & $\mathbf{C}$ & D \\
\hline Leontodon autumnalis subsp. autumnalis & Leo aut & 4.66 & - & - & - \\
\hline Limum catharticum & Lin car & - & - & - & 0.20 \\
\hline Lolium perenne & Lolper & - & 0.67 & - & - \\
\hline Lotus corniculatus & Lot cor & - & 0.17 & - & - \\
\hline Luzula campestris & Luz cam & 1.58 & 0.65 & 0.15 & - \\
\hline Narcissus pseudonarcissus subsp. pseudonarcissus & Nar pse & 0.30 & 5.53 & 9.51 & - \\
\hline Nardus stricta & Nar str & - & 7.21 & - & - \\
\hline Phyteuma orbiculare & Phy orb & - & 1.50 & 2.39 & - \\
\hline Pimpinella saxifraga & Pim sax & 0.78 & 0.52 & 1.35 & 0.07 \\
\hline Plantago lanceolata & Pla lan & 1.88 & 5.70 & 1.83 & 0.28 \\
\hline Plantago major subsp. major & Plamaj & 0.27 & 0.56 & - & - \\
\hline Plantago media & Plamed & - & 4.87 & - & - \\
\hline Poa alpina & Poa alp & - & - & - & 0.13 \\
\hline Poa pratensis & Poa pra & 0.11 & 0.60 & - & - \\
\hline Poa trivialis subsp. trivialis & Poatri & 0.47 & 0.31 & - & - \\
\hline Potentilla aurea & Pot aur & 0.77 & 4.22 & 4.06 & - \\
\hline Potentilla crantzii & Pot cra & - & - & - & 1.48 \\
\hline Potentilla erecta & Potere & 0.20 & 0.85 & 8.22 & 0.03 \\
\hline Prunella vulgaris & Pruvul & 0.72 & - & 0.14 & - \\
\hline Ranunculus acris subsp. friesianus & Ran acr & 6.16 & 3.43 & 0.41 & - \\
\hline Ranunculus nemorosus subsp. nemorosus & Ran nem & 3.41 & 0.09 & 0.70 & - \\
\hline Rhinanthus minor & Rhimin & - & 0.35 & - & - \\
\hline Rumex acetosa & Rum ace & 0.79 & 2.92 & 0.61 & 0.03 \\
\hline Sanguisorba minor subsp. minor & San min & 0.06 & 16.57 & 1.89 & 6.88 \\
\hline Sesleria albicans subsp. albicans & Ses alb & - & - & - & 6.96 \\
\hline Silene nutans subsp. nutans & Sil nut & - & - & - & 1.65 \\
\hline Taraxacum officinale & Tar off & 2.35 & 18.62 & 0.03 & 0.02 \\
\hline Thesium alpinum & The alp & 0.09 & - & - & - \\
\hline Thymus pulegioides & Thy pul & 0.38 & 0.03 & 0.43 & 1.19 \\
\hline Trifolium montamum & Trimon & 0.03 & - & - & 0.03 \\
\hline Trifolium pratense & Tripra & 1.83 & 6.53 & 0.39 & - \\
\hline Trifolium repens & Tri rep & 6.16 & 4.70 & 2.73 & - \\
\hline Trollius europaeus & Tro eur & 0.14 & - & 0.82 & - \\
\hline Veronica chamaedrys subsp, chamaedrys & Ver cha & 6.67 & 0.05 & 9.92 & - \\
\hline Veronica officinalis & Ver off & - & - & 1.51 & - \\
\hline Veronica serpyllifolia subsp. serpyllifolia & Verser & 0.63 & - & 0.14 & - \\
\hline Viola reichenbachiana & Vio rei & - & - & 0.58 & - \\
\hline
\end{tabular}

